\title{
MASALAH KESULITAN DALAM BELAJAR
}

\author{
Marsita Dwi Susanti
}

marsitadwisusanti@gmail.com

\begin{abstract}
ABSTRAK
Pendidikan merupakan suatu sistem yang terdiri dari beberapa komponen untuk mencapai tujuan pendidikan. Dalam Kamus Bahasa Indonesia, tentang Pengertian Pendidikan adalah: Pendidikan berasal dari kata "didik", Lalu kata ini mendapat awalan kata "me" sehingga menjadi "mendidik" artinya memelihara dan memberi latihan. Dalam memelihara dan memberi latihan diperlukan adanya ajaran, tuntutan dan pimpinan mengenai akhlak dan kecerdasan pikiran. Supervisi pendidikan adalah pembinaan yang berupa bimbingan atau tuntunan ke arah perbaikan situasi pendidikan pada umumnya dan peningkatan mutu mengajar dan belajar dan belajar pada khususnya. Administrasi supervisi pendidikan merupakan pembinaan yang direncanakan bagi personel dalam proses kerjasama di bidang pendidikan dan peningkatan sumber daya material dalam rangka perbaikan situasi pengajaran untuk mencapai tujuan pendidikan lebih efektif dan efesien.
\end{abstract}

Kata Kunci : Pendidikan, Supervisi pendidikan.

\section{PENDAHULUAN}

\section{A. Latar Belakang}

Administrasi supervisi pendidikan merupakan pembinaan yang direncanakan bagi personel dalam proses kerjasama di bidang pendidikan dan peningkatan sumber daya material dalam rangka perbaikan situasi pengajaran untuk mencapai tujuan pendidikan lebih efektif dan efesien. Administrasi supervisi pendidikan memiliki unsur penting sebagai berikut:

a. Aktivitas pembinaan yang direncanakan

b. Perbaikan situasi pengajaran (belajar-mengajar)

c. Mengefektifkan para guru, pegawai sekolah, dan sumber material lainnya

d. Pencapaian tujuan pendidikan lebih efektif dan efesien. 
Administrasi pendidikan bertujuan untuk mencapai tujuan pendidikan. Dalam mencapai tujuan pendidikan terkadang murid/siswa mengalami kesulitan dalam belajar dan mengerjakan tugasnya, murid/siswa terkadang memiliki kekurangan motivasi saat belajar, sehingga terkadang jalannya pembelajaran masih memiliki kendala dan belum stabil.

\section{B. Rumusan Masalah}

1. Apa saja permasalahan dari pelaksanaan Supervisi Pendidikan di Sekolah?

2. Bagaimana alternatif pemecahan permasalahan pelaksanaan Supervisi Pendidikan di Sekolah?

\section{Tujuan Penulisan.}

1. Menambah pengetahuan tentang permasalahan dan pemecahan masalah pelaksanaan Supervisi Pendidikan di Sekolah

2.Membahas secara sederhana permasalahan dan pemecahan masalah pelaksanaan Supervisi Pendidikan di Sekolah.

\section{PEMBAHASAN}

Pendidikan merupakan suatu sistem yang terdiri dari beberapa komponen untuk mencapai tujuan pendidikan. Dalam Kamus Bahasa Indonesia, tentang Pengertian Pendidikan adalah: Pendidikan berasal dari kata "didik", Lalu kata ini mendapat awalan kata "me" sehingga menjadi "mendidik" artinya memelihara dan memberi latihan. Dalam memelihara dan memberi latihan diperlukan adanya ajaran, tuntutan dan pimpinan mengenai akhlak dan kecerdasan pikiran.

Salah satu komponen yang menunjang berlangsungnya proses pendidikan disekolah adalah pengawas sekolah. Pengawasan sekolah itu penting karena merupakan mata rantai terakhir dan kunci dari proses manajemen. Kunci penting dari proses manajemen sekolah yaitu nilai fungsi pengawasan sekolah terletak terutama pada hubungannya terhadap perencanaan dan kegiatan-kegiatan yang didelegasikan. Dalam proses pendidikan, pengawasan atau supervisi merupakan bagian tidak terpisahkan dalam upaya peningkatan prestasi belajar dan mutu sekolah. Supervisi pendidikan adalah pembinaan yang berupa bimbingan atau tuntunan ke arah perbaikan situasi pendidikan pada umumnya dan peningkatan mutu mengajar dan belajar dan belajar pada khususnya.

Menurut Ahmad Sabandi dalam jurnal "PEDAGOGI" (2013 : hal. 2), Supervisi pendidikan berkembang seiring berkembangkan ilmu manajemen. Pada awal perkembangannya, supervisi d ilakukan dengan pendekatan inspeksi. Supervisor datang ke sekolah dan 
mengamati guru mengajar. Fokus perhatian supervisor adalah menemukan kesalahan guru berdasarkan standar kerja baku yang dirumuskan sedemikian rupa oleh otoritas pendidikan. Guru melaksanakan tugas sesuai dengan prosedur operasional yang standar. Super visor dengan guru merupakan dua pihak sebagai atasan-bawahan. Supervisor memiliki tingkat kebenaran yang lebih tinggi dari pada guru

\section{Masalah kesulitan belajar}

Selama ini ada pendapat yang keliru dengan mengatakan bahwa kesulitan belajar anak didik di sebabkan oleh rendahnya inteligensi. Karena dalam kenyataannya cukup banyak anak didik yang memiliki intilegensi yang tinggi, tetapi hasil belajarnya rendah, jauh dari yang di harapkan. Dan masih banyak anak didik dengan intelegensi yang rata-rata normal, tetapi dapat meraih prestasi belajar yang tinggi.

Kesulitan belajar yang dirasakan oleh anak didik bermacam-macam, yang dapat di kelompokan menjadi empat macam, yaitu sebagai berikut:

1. Dilihat dari jenis kesulitan belajar

2. Dilihat dari mata pelajaran yang di pelajari.

3. Dilihat dari sifat kesulitannya.

4. Dilihat dari segi faktor penyebabnya.

Berdasarkan uraian di atas, dapat di simpulkan bahwa kesulitan belajar adalah suatu kondisi dimana anak didik tidak dapat belajar secara wajar, di sebabkan adanya ancaman, hambatan ataupun gangguan dalam belajar.

Para ahli mengemukakan fakto-faktor kesulitan belajar dengan sudut pandang mereka masing-masing. Ada yang meninjaunya dari sudut Intren anak didik dan ekstern anak didik.

a. Faktor-faktor intern anak didik:

1) Rendahnya kapasitas intlektual/integensi anak didik.

2) Labilnya emosi dan sikap.

3) Terganggunya alat-alat indra penglihatan dan pendengaran.

b. Faktor-faktor ekstern anak didik:

1) Lingkungan keluarga, contohnya: ketidak harmonisan hubungan antara ayah dan ibu, dan rendahnya kehidupan ekonomi keluarga.

2) Lingkungan perkampungan/masyarakat, contohnya; wilayah perkampungna kumuh dan teman sepermainan yang nakal. 
3) Lingkungan sekolah, contohnya kondisi dan letak sekolah yang buruk seperti dekat pasar, kondisi guru serta alat-alat belajar yang berkualitas rendah.

Maka faktor-faktor penyebab kesulitan belajar anak didik dapat di bagi menjadi faktor anak didik, sekolah, keluarga dan masyarakat.

\section{Faktor anak didik}

Inteligensi yang kurang baik, Bakat yang kurang, Faktor emosional yang kurang stabil, Aktifitas belajar yang kurang, kebisaan belajar yang kurang baik, Penyusaian sosial yang sulit, Latar belakang pengalaman yang pahit.

\section{Faktor sekolah}

Pribadi guru yang kurang baik, Guru kurang berkualitas, Hubungan guru dengan anak didik kurang harmonis, Gurru menuntut setandar pelajran di atas kemampuan anak, Guru tidak memiliki kecakapan dalam usaha mendiagnosis kesulitan belajar anak didik, Cara guru mengajar yang kurang baik, Alat/media yang kurang memadai.

\section{Faktor keluarga.}

Kurangnya kelengkapan alat-alat belajar bagi anak dirumah, Kurang nya biaya pendidikan yang disediakan oarangtua, Anak tidak memiliki ruang dan tempat yang belajar khusus dirumah, Ekonomi keluarga yanmg terlalu lemah atau tinggi yang membuat anak berlebi-lebihan, Perhatian orang tua yanmg tidak memadai, Kedudukan anak dalam keluarga yang menyedihkan.

\section{Faktor masyarakat.}

Pergaulan yang terkadang kurang bersahabat, sering memicu konplek sosial. Keributan pertengkaran, perampokan, pembunuhan, perjudian, dan perilaku jahiliyah lainya sudah menjadi santapan sehari-hari dalam masyarakat.

Usaha Mengatasi Beberapa Masalah Supervisi Pendidikan Islam

Beberapa masalah dalam supervisi pendidikan islam adalah faktor peserta didik, yang mengalami kesulitan belajar dan usaha mengatasinya:

1. Pengumpulan data, melalui kegiatan kunjungan rumah, Case study, Case history, Daftar pribadi, Meneliti pekerjaan anak, Melaksanakan test, baik test IQ maupun test prestasi

2. Pengolahan data yaitu Identifikasi kasus, Membandingkan antar kasus, Membandingkan dengan test lisan, Menarik kesimpulan

3. Diagnosis yaitu keputusan (penentuan) mengenai hasil dari pengolahan data. Contohnya berupa keputusan mengenai jenis kesulitan belajar anak didik yaitu berat 
dan ringannya tingkat kesulitan yang dirasakan anak didik, keputusan mengenai faktorfaktor yang ikut menjadi sumber penyebab kesulitan belajar anak didik, dsb.

4. Treatment adalah perlakuan yakni : pemberian bantuan kepada anak didik yang mengalami kesulitan belajar sesuai dengan program yang telah disusun pada tahap prognosis. Bentuk treatment yang mungkin dapat diberikan adalah: Melalui bimbingan belajar individual, Melalui bimbingan belajar kelompok, Melalui remedial teaching untuk mata pelajaran tertentu, Melalui bimbingan orang tua di rumah, dan lain sebagainya.

5. Evaluasi dimaksudkan untuk mengetahui apakah treatment yang telah diberikan berhasil dengan baik. artinya ada kemajuan.

\section{Kesimpulan:}

Kesulitan belajar yang dirasakan oleh anak didik bermacam-macam, yang dapat di kelompokan menjadi empat macam, yaitu sebagai berikut:

1. Dilihat dari jenis kesulitan belajar

2. Dilihat dari mata pelajaran yang di pelajari.

3. Dilihat dari sifat kesulitannya.

4. Dilihat dari segi faktor penyebabnya.

Para ahli mengemukakan fakto-faktor kesulitan belajar dengan sudut pandang mereka masing-masing. Ada yang meninjaunya dari sudut Intren anak didik dan ekstern anak didik. Dilihat dari faktor-faktor internal dan eksternal anak maka faktor-faktor penyebab kesulitan belajar anak didik dapat di bagi menjadi faktor anak didik, sekolah, keluarga dan masyarakat. Di lihat dari masalah instrumennya yaitu kurikulum, proran, sarana dan fasilitas dan guru. Adapun usaha-usaha mengatasi masalah supervisi pendidikan Islam tentang masalah kesulitan belajar anak didik dapat dilakukan dengan cara pengumpulan data, pengelolaan data, diagnosis, prognosis, treatment dan evaluasi.

\section{REFERENSI}

Ahmad Sabandi. 2013. Dalam Jurnal IImiah Ilmu Pendidikan "PEDAGOGI”

Bahri Djamarah, Syaiful. 2008. Psikologi Belajar, Jakarta: PT. Rineka Cipta.

Rohani, Ahmad. 2004. Pengelolaan Pengajaran. Jakarta: PT Reneka Cipta. Http://ejournal.unp.ac.id/index.php//pedagogi 
